\title{
The evaluation of adaptation systems for apricot culture in the phases of its development for selection improvement and location of the future varieties in conditions of climate fluctuation
}

\author{
Irina Dragavtseva ${ }^{1 *}$, Tatiana Salova ${ }^{2}$, Anna Kuznetsova ${ }^{1}$, and Anna Klyukina ${ }^{1}$ \\ ${ }^{1}$ Federal State Budget Scientific Institution «North Caucasian Federal Scientific Center of \\ Horticulture, Viticulture, Wine-making», 39 str. 40 Let Pobedy, Krasnodar, 350901, Russia \\ ${ }^{2}$ International Fund of Malus Sieversii Conservation, Alma-Aty, Kazakhstan
}

\begin{abstract}
Apricot is one of the most valuable fruit cultures. This is a minor culture in Russia and other countries primarily because of irregular fruit-bearing by the reason of its flower buds death in the winter and spring period, caused by the low temperatures. The increased regularity of its fruit-bearing may be achieved in two primary ways: the creation of new varieties, more resistant to the temperature fluctuations of the winter and spring period and their rational allocation in the zones and microzones of the growing territories. The solution of both set tasks calls for the knowledge of protective and adaptive reactions of genotypes in the stages of their development. The investigations of the last years showed the levels of agricultural plants productivity to be determined not only by the genes of quantitative characters, but to significant extent by the effects of their interaction with environment at the different stages of the plants development. As a new factor of outdoor environment, limiting the growth and development of plants becomes evident, the spectrum and number of genes, determining one and the same quantitative character (freezing tolerance in this case) is changed at the particular stage of development on a particular territory. The climatic change permits to analyze more profoundly the regularities in manifestation of genotype peculiarities in phenotype. The response of apricot culture (Armeniaca vulgaris) to display of the winter temperature stresses in the different stages of temporal (19902019) and spatial - Krasnodar and Stavropol Territory, Kabardino-Balkar Republic and Kazakhstan - development was studied. The analysis was undertaken for the new terms of deadly temperatures occurrence at the different stages of development. There was studied mechanism of the apricot culture biological potential realization in the new temperature conditions in the phases of winter and spring period, permitting to open the more efficient process of apricot selection for freezing tolerance and its rational location.
\end{abstract}

*Corresponding author: i_d@list.ru 


\section{Introduction}

The creation of the new fruit cultures contemplated always the knowledge of relationship between their genetic systems and peculiarities of the growing environment. At the present time, in connection with the global change in climate, there is much concern about the protective and adaptive reactions of genotypes to the temperature limits of temporal and spatial environment changing [1-8].

The global (on the non-mountainous territories) and local (in the mountains and submountain areas) fluctuations of climate [9-11], available at the present moment, caused the disturbance of balance in occurrence of phenological stages of development, as well as in time and place of occurrence of temperature conditions destructive to the yield in winter and spring period. The changes in response of the plants in the stages of their development to the new uncomfortable conditions of environment permit to make known the genetically conditioned adaptability of fruit cultures and their varieties at the particular stages of development to the stress situations and employ this knowledge, both in selection of fruit cultures, and in correction of their location [12-14].

\subsection{Objective}

The study of protective and adaptive reactions of apricot to the temperature limits of winter and spring development in the ontogenesis stages to elaborate the directions of apricot selection and location of its varieties.

\section{Methodological approaches and place of investigation}

The present paper deals with the changes in climate over a long period of years - the data of meteorological stations of Krasnodar, Stavropol, Nalchik (North Caucasus) and meteorological station of Almaty (Republic of Kazakhstan).

The response of apricot, growing in the above-said regions, to the stress situations of winter and spring period was studied. The years of investigation - 1990-2019.

\section{Results of investigation}

The selection of the new varieties of fruit cultures shall be directed to adaptation to the winter and spring period stresses, as the most destructive one to the fruit plants [15].

The biological potential of plants (especially of the plurannual fruit plants) covers all the spectrum of its characters variability (including the exhibition of new properties "emergent"), resulting from interaction of genotype and environment. What is interesting, breeding of a new variety with the prescribed genetic peculiarities and their manifestations in phenotype calls for the knowledge of varieties reaction to the uncontrollable limits of environment in each stage of ontogenesis. Besides, the knowledge of the probable gradients of environment to grow the varieties under formation is necessary.

The fluctuation of climate, taking place at the present period, produces changes in the time-frame of passing phenological phases, strength and time of destructive stresses occurrence, in other words it permits to lay open the mechanism of biological potential realization at the particular stages of development and, consequently, the new opportunities of its functioning. The realization of the fruit plants biological potential is closely associated with environment, having the temporal changes. Besides, it is regulated also by the agrobiocenotic factors of particular territories. 
To investigate the effects of climatic fluctuations on manifestations of the stress temperature values there were analyzed the critical minimum temperatures of apricot culture (exemplified by Krasnoshchekiy variety) in phenological phases of their development according to the data of the Federal State Budgetary Scientific Organization "North Caucasus Federal Scientific Center for Horticulture, Viticulture, Winemaking" and state variety test plots of the North Caucasus, as well as the data provided by the fruit plants department of Kazakhstan Academy of Science Main Botanic Garden (Table 1). Krasnoshchekiy variety was involved in investigations as one of the mostly distributed in Russia and Kazakhstan. The only one among all the varieties of apricot, which is in areaspecific assortment of the south of Russia, beginning from 1947.

Table 1. The critical minimum temperature for apricot in phenological phases of development, ${ }^{\circ} \mathrm{C}$ (average values) for the south of Russia and Zailiyskiy Alatau (Kazakhstan)

\begin{tabular}{|l|l|l|}
\hline $\begin{array}{c}\text { Phonological phases of } \\
\text { development }\end{array}$ & \multicolumn{1}{|c|}{$\begin{array}{c}\text { Temperatures in the } \\
\text { North Caucasus }\left({ }^{\circ} \mathrm{C}\right)\end{array}$} & $\begin{array}{l}\text { Temperatures in submountain areas } \\
\text { of the Republic of Kazakhstan }\left({ }^{\circ} \mathrm{C}\right)\end{array}$ \\
\hline Exogenous dormancy & January, I, II, $-24^{\circ} \mathrm{C}$ & $\begin{array}{l}\text { January, III, }-28^{\circ} \mathrm{C} \\
\text { February, I, II, }-24{ }^{\circ} \mathrm{C}\end{array}$ \\
\hline Swelling of flower buds & $\begin{array}{l}\text { January, III; February, } \\
\text { I, II, } \\
-23^{\circ} \mathrm{C} ; \\
\text { February, III, } \\
-20^{\circ} \mathrm{C}\end{array}$ & February, III, $-20^{\circ} \mathrm{C}$ \\
\hline Bursting of flower buds & March, I, II, $-10^{\circ} \mathrm{C}$ & March, I, II, $-10^{\circ} \mathrm{C}$ \\
\hline Appearance of petals & March, III, $-5^{\circ} \mathrm{C}$ & March, III, $-5^{\circ} \mathrm{C}$ \\
\hline Blossoming & April, I, $-3^{\circ} \mathrm{C}$ & April, I, $-3^{\circ} \mathrm{C}$ \\
\hline Primordium & April, III, $-1^{\circ} \mathrm{C}$ & April, III, $-1^{\circ} \mathrm{C}$ \\
\hline
\end{tabular}

The most vulnerable phases of apricot winter and spring period over a long period of years in the different geographical points (Russia and Kazakhstan) were studied.

Figure 1 provides the manifestation of destructive temperature stresses in the stages of development in Krasnodar Territory (meteorological station of Krasnodar, altitude above the sea level $(\mathrm{h})=29 \mathrm{~m})$ for 2 time periods $(1990-2010$ and 2011-2019).

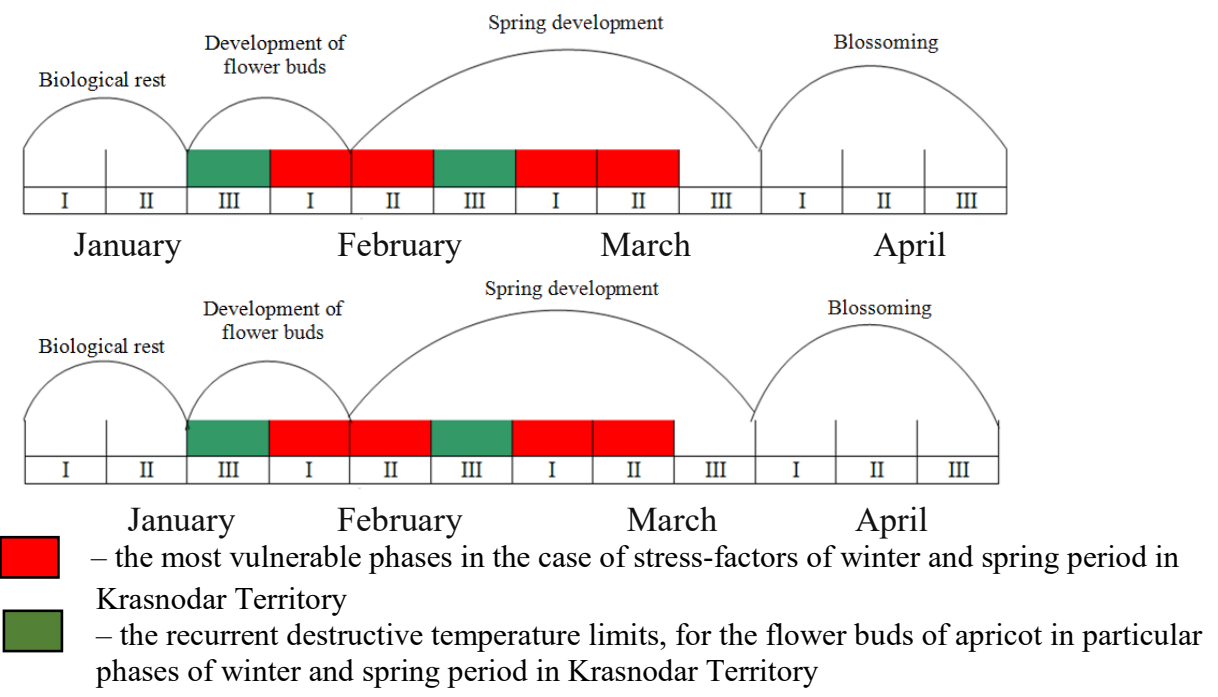

Fig. 1. The most vulnerable phases of apricot development as the new temperature stresses become evident in the phases of development (meteorological station of Krasnodar). Period of 1990-2019. 
As it follows from Figure 1, the most vulnerable phases for successful fruit-bearing of apricot in the non-mountainous territories of Krasnodar Territory are the third ten-day period of January and the third ten-day period of February.

The time of destructive stresses occurrence to grow apricot in Stavropol Territory - first third of April (Fig. 2).

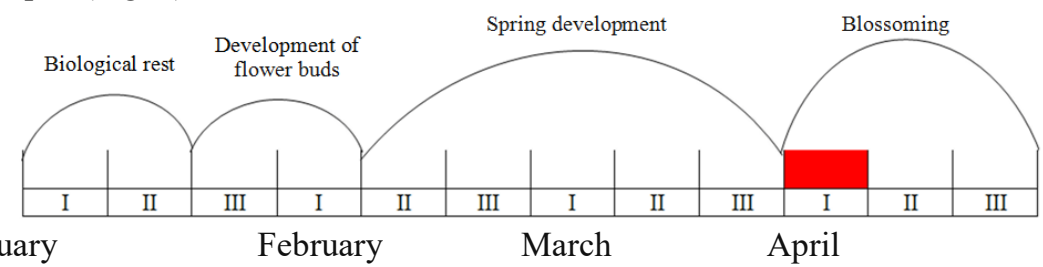

- the most vulnerable phases in the case of stress-factors of winter and spring period in Stavropol Territory

Fig. 2. The most vulnerable phases of apricot development in Stavropol Territory as the new temperature stresses become evident in the phases of development (meteorological station of Stavropol, h=650 м), 1990-2019.

The local changes in climate, associated with altitude above the sea level become visible in another way. Destructive for the flower buds of fruit cultures in Kabardino-Balkar Republic (meteorological station of Nalchik, $\mathrm{h}=465 \mathrm{~m}$ ) began to be evident more frequently at the stage of biological rest and exogenous dormancy (Fig. 3).
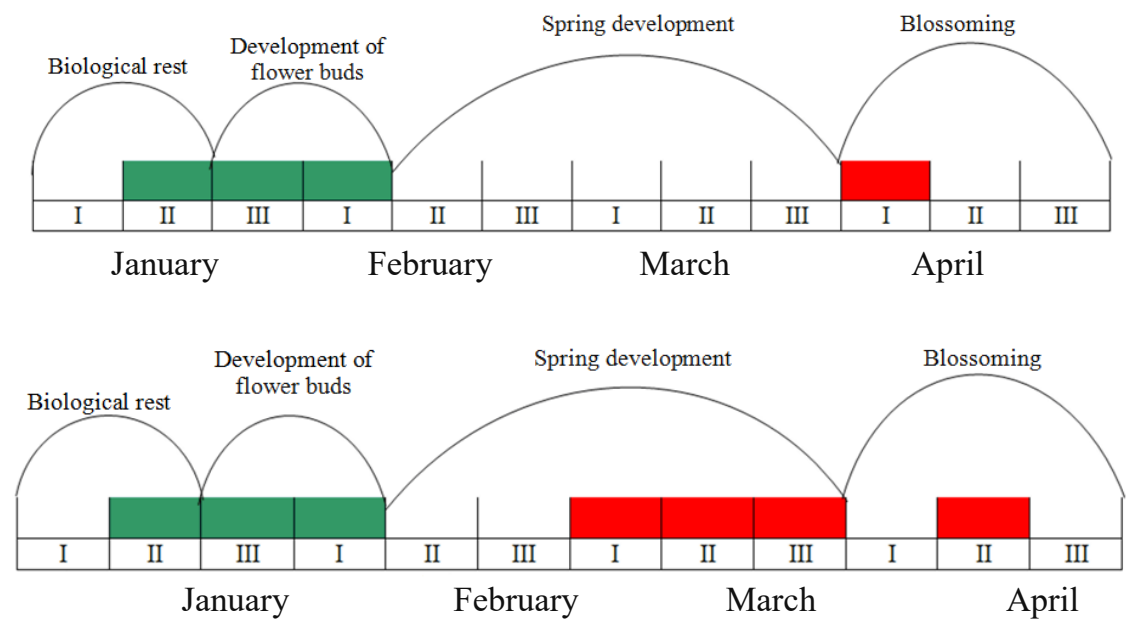

- the most vulnerable phases in the case of stress-factors of winter and spring period in submountain areas of Kabardino-Balkar Republic

- the recurrent destructive temperature limits, for the flower buds of apricot at the particular stages of winter and spring period in submountain areas of KabardinoBalkar Republic

Fig. 3. The most vulnerable phases of apricot development in submountain areas of Kabardino-Balkar Republic as the new temperature stresses appear in the stages of development over 1986-2017.

The primary reason of the flower buds death through the destructive temperatures of a winter and spring period in submountain areas of Zailiyskiy Alatau (Republic of Kazakhstan) are the frosts in March and April. In 1990-2005 period these were the case during March and April - more frequently in April. In 2006-2019 period the number of frosts decreased in March (1st-2nd third), and in April the frosts ended in the last third (Fig. 4). 

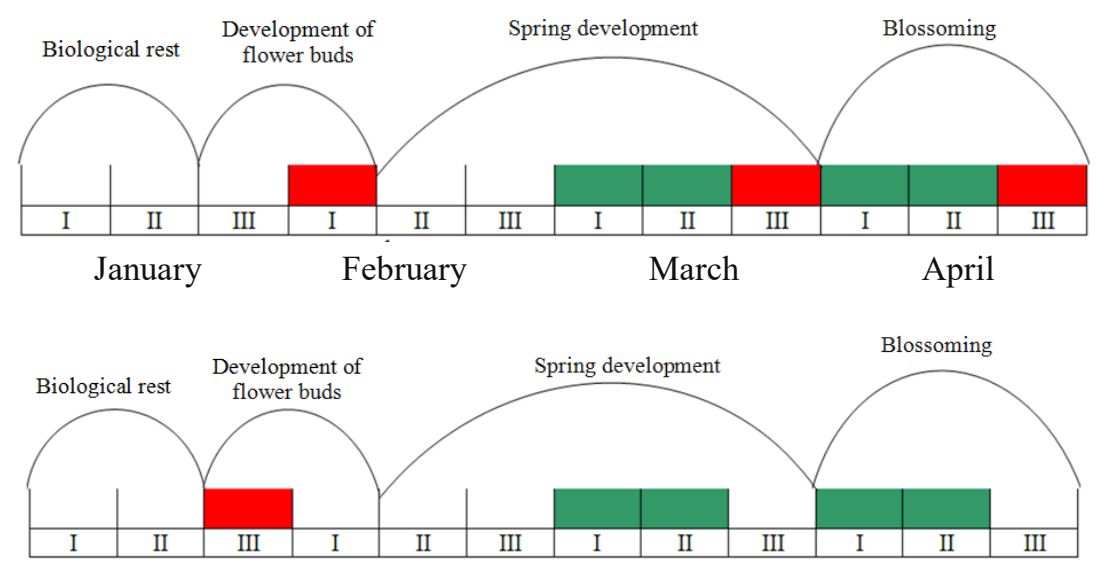

January

February

March

April

- the most vulnerable phases in the case of stress-factors of a winter and spring period in Alma-Ata

- the recurrent destructive temperature limits, for the flower buds of apricot at the particular

stages of a winter and spring period in Alma-Ata.

Fig. 4. The most vulnerable phases of apricot development as the new temperature stresses appear in the stages of development (meteorological station of Alma-Ata, $h=848$ м). Period of 1990-2019.

This, in both periods the death of the flower buds in the 1st, 2nd third of March and in the 1st, 2nd third of April remained highly probable in submountain areas of Zailiyskiy Alatau.

Consequently, the freezing tolerance of apricot in the different terms and conditions of growing (temporal and spatial) is determined by the combination of the gene products activity at each phase of development, that should be taken into account during its selection and their responses to manifestation of the temperature stresses.

The newly created varieties must be adapted to the primary destructive peaks of limfactors at the particular phases of development and in particular geographical point. This approach shall be employed to engineer the selection technology, when identifying the sources and donors of the fruit cultures adaptivity systems in the stages of their winter and spring development.

\section{Conclusion}

1. The temporal and spatial climatic fluctuations permit to conceive more profoundly the regularities of genetic and phenotypic changes of fruit cultures, when changing the limits of outdoor environment and, consequently, to control their productivity more competently.

2. It has been placed beyond a doubt that "genotype-temperature conditions of a winter and spring period" interaction differs depending on the global and local change of climate.

3. The analysis of translocating the parametric temperature environment factors, having a tendency to the change in the new climatic conditions, permits to confirm that:

- It is necessary to increase through selection the frost resistance of apricot in the last third of January (down to $\quad-25^{\circ} \mathrm{C}$ ) and in the last third of February (down to $-22^{\circ} \mathrm{C}$ ) for the non-mountainous territories of Krasnodar Territory;

- Stavropol Territory needs the apricot varieties with increased freezing tolerance (down to $-4^{\circ} \mathrm{C}$ ) in the 1 st third of April; 
- The submountain territories of Krasnodar Territory in the terms and conditions of climatic changes need the varieties with increased freezing tolerance at the stage of biological rest and exogenous dormancy (down to $-25^{\circ} \mathrm{C}$ ) and at the blooming stage (down to $\left.-4^{\circ} \mathrm{C}\right)$.

\section{References}

1. J. Rajatiya, D. K. Varu, P. Gohil, M. Solanki, F. Halepotara, M. Gohil, P. Mishra, R. Solanki, Int. J. Pure App. Biosci, 6(1), 1161-116 (2018). https://doi.org/10.18782/2320$\underline{7051.6161}$

2. C. Körner, D. Basler, Science. 327(5972), 1461-1462 (2010). https://doi.org/10.1126/science.1186473

3. R. Viti, S. Bartolini, L. Andrein, Europ. J. Hort. Sci., 75(5), 185-192 (2010). URL: https://www.researchgate.net/publication/287749884_Flower_Bud_Frost_Tolerance_of_S everal_Italian Apricot_Genotypes

4. E. Luedeling, E. H. Girvetz, M. A. Semenov, P. H. Brown, PLoS One. 6(5), 1-27 (2011). https://doi.org/10.1371/journal.pone.0020155

5. E. Luedeling, P. H Brown. International Journal of Biometeorology. 55(3), 411-42 (2011). URL: https://link.springer.com/article/10.1007/s00484-010-0352-y

6. A. G. Rodríguez, D. Pérez-López, E. Sánchez, A. Centeno, I. Gómara, A. Dosio, M. Ruiz-Ramos, Nat. Hazards Earth Syst. Sci., 19(5), 1087-1103 (2019). https://doi.org/10.5194/nhess-19-1087-2019

7. F. M. Chmielewski, K. Blümel, I. Pálešová. Clim. Res. 54, 209-219 (2012). https://doi.org/10.3354/cr01115

8. R. Ray, S. Joshi, S. Roy, O. Singh, M. Samir, A. Chandra, Journal of Horticulture. 2(2), 1-6 (2015). https://doi.org/10.4172/2376-0354.1000135

9. I. A. Dragavtseva, V. A. Dragavtsev, I. L. Yefimova, A. P. Kuznetsova, A. V. Klyukina, IJAST. 29, 1971-1983 (2020). URL: https://sersc.org/journals/index.php/IJAST/article/view/17127

10. V. A. Dragavtsev, I. A. Dragavtseva, I. L. Efimova, A. P. Kuznetsova, A. S. Morenets, Agricultural Biology. 1, 151-156 (2018). https://doi.org/10.15389/agrobiology. 2018.1.151eng

11. E. Ivits, M. Cherlet, G. Tóth, S. Sommer, W. Mehl, J. Vogt, F. Micale, Global and Planetary Change. 88-89, 85-97 (2012). https://doi.org/10.1016/j.gloplacha.2012.03.010

12. E. Balogh, J. Halasz, A. Solteszt, G. Galiba, A. Hegedus. Z. Erös-Honti, Á. Gutermuth, L. Szalay, M. Höhn, A. Vágújfalvi, Front. Plant. Sci. 10, 402 (2019). https://doi.org/10.3389/fpls/2019.00402

13. J. A. Campoy, D. Ruiz, L. Allderman, N. Cook, J. Egea, Eur. J. Agron. 37, 43-55 (2012). https://doi.org/10.1016/j.eja.2011.10.004

14. E. Fadón, Sara P. Herrera, Brenda I. Guerrero, M. E. Guerra, J. Rodrigo. Agronomy, 10(3), 409 (2020). https://doi.org/10.3390/agronomy10030409

15. F. Razavi, J. Hajilou, S. Tabatabaei, M. Dadpour, Res. Plant Biol. 1, 40-47. (2011)

.URL: https://www.researchgate.net/publication/297739059 